\title{
段差および階段に設置可能な車いす用昇降支援システム
}

情野 瑛 $^{* 1}$, 衣川 潤 ${ }^{* 1}$, 若林 勇太 ${ }^{* 2}$, 伊丹 翔一 ${ }^{* 3}$, ブーラナアモン タナパ*4, 小菅一弘 ${ }^{* 5}$

\section{Wheelchair lift which is installable both of steps and stairs}

\author{
Akira SEINO $^{* 1}$, Jun KINUGAWA*1, Yuta WAKABAYASHI ${ }^{* 2}$, Shoichi ITAMI*3, \\ Tanapat BURANAAMON ${ }^{* 4}$ and Kazuhiro KOSUGE ${ }^{* 5}$ \\ ${ }^{*} 1,{ }^{5}$ Department of Robotics, Graduate School of Engineering, Tohoku University \\ 6-6-01 Aoba, Aramaki, Aoba-ku, Sendai 980-8579, Japan \\ ${ }^{*} 2$ Department of Control Engineering, National Institute of Technology, Maizuru College \\ 234 Shiroya, Maizuru-shi, Kyoto 625-8511, Japan \\ ${ }^{* 3}$ DENSO Corp. \\ 1-1 Showa-cho, Kariya-shi, Aichi 448-8661, Japan \\ ${ }^{* 4}$ EASY BUY Public Co., Ltd. \\ 5th Floor, Sathorn Square Office Tower, 98 North Sathorn Road, Silom, Bangrak, Bangkok 10500, Thailand
}

\section{Received: 11 February 2019; Revised: 4 April 2019; Accepted: 10 May 2019}

\begin{abstract}
This study proposes a novel step and stair lifting system for wheelchair. In general households, it is difficult for setting the step/stair lift to provide a large space at the front of the entrance, because the size of the system is very large. In addition, the system requires an actuator separate from the lifting drive for folding the platform and wheel-stops. As the number of actuators increases, the scale of the system also increases. Therefore, a stair and step lifting system were designed to satisfy these concepts as follows: 1) do not occupy the space in lower floor side, 2) stair and step common system, and 3) one degree of freedom mechanism. Based on these concepts, the proposed system has only one degree of freedom for driving rail to lift platform, and can be installed at both the stairs and the step by changing the inclination of the driving rail. In this paper, the designs for the step and stair of the proposed system are described. Furthermore, mechanisms for folding a platform and mechanisms for opening and closing wheel-stops are proposed using the lifting drive. For lifting motion, the disturbance observer is integrated to the control system. Finally, the effectiveness of the proposed systems are elucidated through the experiments.
\end{abstract}

Keywords : Welfare system, Mechanical design, Disturbance observer

1. 緒言

内閣府の調査によると，人口が減少する一方で高齢者の割合は増加し，2065 年に 65 歳以上の人口の割合は $38.4 \%$ に達すると予想されている (内閣府，2018)，高齢者の抱える問題として身体機能の低下が挙げられ，通常であれば 移動の妨げとならないような歩道や階段の段差等の障害物が高齢者の移動を妨げる要因となる可能性がある.ま た，国民生活センターによる事故事例調査によると，全ての事故発生件数の中で住宅内の事故発生件数が最多で

No.19-00063 [DOI:10.1299/transjsme.19-00063], J-STAGE Advance Publication date : 20 May, 2019

${ }^{*} 1$ 正員, 東北大学大学院工学研究科ロボティクス専攻 (厂980-0879 宮城県仙台市青葉区荒巻字青葉 6-6-01)

*2 正員，舞鶴工業高等専門学校電子制御工学科（广 625-8511 京都府舞鶴市白屋 234）

*3 (株) デンソー（テ448-8661 愛知県刈谷市昭和町 1-1）

${ }^{* 4}$ EASY BUY Public Co., Ltd. (5th Floor, Sathorn Square Office Tower, 98 North Sathorn Road, Silom, Bangrak, Bangkok 10500, Thailand)

*5 正員, フェロー，東北大学大学院工学研究科ロボティクス専攻

E-mail of corresponding author: seino@irs.mech.tohoku.ac.jp 
Seino, Kinugawa, Wakabayashi, Itami, Buranaamon and Kosuge,

Transactions of the JSME (in Japanese), Vol.85, No.874 (2019)

あり, その中でも 65 歳以上の高齢者の場合は, 特に重傷を負う可能性のある階段・段差での事故割合が高いこと が報告されており（国民生活センター, 2018），今後高齢者数が増加することで，階段や段差における事故の発生 件数はさらに増加すると考えられる．平成 20 年度の国土交通省の調査によると 65 歳以上の高齢者の全人口の約 96\%が在宅介護者であり (国土交通省住宅局住環境整備室, 2018), 住宅内のバリアフリー化が進んでいる. 住宅内 のバリアフリー化として, 手すりの設置および低段差および段差のない住宅が増加傾向である一方で, 車いすを 屋内で利用することや車いすを利用して住宅内へ乗り込むことについては増加傾向にあるが，進展が遅れている 傾向が見られる (総務省, 2018).

そこで近年，安全に階段や段差を移動するための福祉機器（フロア間昇降機器）やロボットの補助による支援 機器の研究開発が盛んに行われている．車いす利用者が階段や段差を移動するための既存のシステムを分類する と, 人間が搭乗する移動機器自体に階段や段差を乗り越えられる機能を付加する方法と, 通常の車いすが階段や 段差を移動するための機器を階段や段差に設置する方法の 2 つに分けられる. 人間が搭乗する移動機器の車輪等 に機構を加え, 階段昇降を可能にしたシステムとして, 柳原らは車輪のついた回転十字アームを用いて階段に対 してローラが乗りあげながら昇降を行う階段昇降車いす QUATTRO-I を提案し (柳原他, 2000), 菅原らは 4 節リン ク機構を用いた階段を昇降する車いす TBW-1 Matsushima を提案した（菅原他, 2011）。また，佐々木らは回転脚 機構を用い, 上半身の運動機能であれば単独で階段の踏破が可能な車椅子型移動機器を提案している (佐々木他, 2015). 一方で, 通常の車いすが階段や段差を移動するための階段や段差に設置するフロア間昇降機器としては, まず車いす用階段昇降機が挙げられる (中央エレベータ工業, 2019)(マイクロエレベーター, 2019)。これは, 壁や 床にレールを設置し，そのレールに沿って車いすを載せるカゴが昇降するシステムである．段差用昇降支援機器 も市販されており, 家庭用のホームエレベータ (三菱日立ホームエレベータ株式会社, 2017) や, 車いす用の段差解 消機 (SD エレメイク, 2019)(中央エレベータ工業, 2019) などが挙げられる. 車いす用の段差解消機はチェーンとス プロケットを用いた昇降レールを用いる方法 (SD エレメイク, 2019) や，パンダグラフ機構を用いる方法 (中央エ レベータ工業, 2019) などが存在する. また, 段差昇降リフトとしては, 福祉車両へ車いすで乗り入れを行うため の昇降リフトが挙げられる (和光工業株式会社，2019). 福祉車両用の昇降リフトは，車いすが搭乗するためのプ ラットフォームを車内から電動または油圧アームを用いて昇降を行う。このように様々な方法で階段や段差を移動 するための機器が研究開発されている.

昇降用の機器を用いることにより, 高齢者の階段や段差における転倒・転落事故は大幅に減少し, これらの機 器が一般的に普及することで, 高齢者が玄関先の階段や縁側の掃出し口, カーポート・車庫から家への出入り口 等を使用して移動するのが容易になるため, 高齢者の住宅内から住宅外への行動範囲が広がり, 社会生活への積 極的な参加ができるようになることが期待される．しかしながら，これら多くのフロア間昇降用機器は一般家庭 に対して見ると，高コストであることや大規模な工事が必要であることから導入は進んでいない．また，一般的 な昇降用機器は大型で, 設置に広いスペースを要するものが多く, 都市部周辺等の敷地面積が狭い住宅では, 設 置可能な昇降機が限定されてしまう問題がある.そこで本研究では様々な昇降用の機器の中でも, 介助者を必要 とせず，省スペースで利用可能である車いす用段差解消機に注目し，設置スペースが十分に確保できない一般家 庭の玄関口などを対象として，階段や段差に設置できる新たな車いす用昇降支援システムを提案する．本稿では， 新たに共通の駆動部を用いて段差昇降に対応するシステムと階段昇降に対応するシステムを提案し, 機構設計お よび制御手法について説明する．最後に，実験から提案するシステムの有効性について検証を行う.

\section{2. 車いす用昇降支援システム}

\section{$2 \cdot 1$ コンセプトおよびハードウェア構成}

本研究が対象とする段差昇降システムの設置場所は一般家庭における玄関先や車庫・カーポートなど屋外から屋 内へ移動する場所を想定している。これらの場所では. 下階（段差下）が道路に面していることや十分なスペー スが確保しにくいことが要因で設置が困難である場合が多い, 従って, 設置のために玄関自体の改装が必要とな らない下階側を専有しないシステムが望ましい，また，階段へ昇降支援システムを設置する場合，一般的に階段 の一部を撤去し, 段差解消機を設置する必要がある.しかし, この場合健常者が使用する階段幅が確保できなく なるため, 幅の狭い階段でも階段を除去することなく設置可能なシステムが望ましい，通常車いす昇降支援シス 


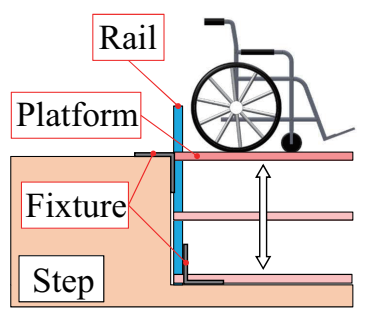

(a) Steplift image.

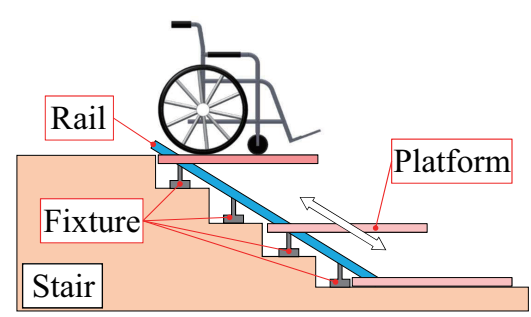

(b) Stairlift image.

Fig. 1 The concepts of the proposed system.

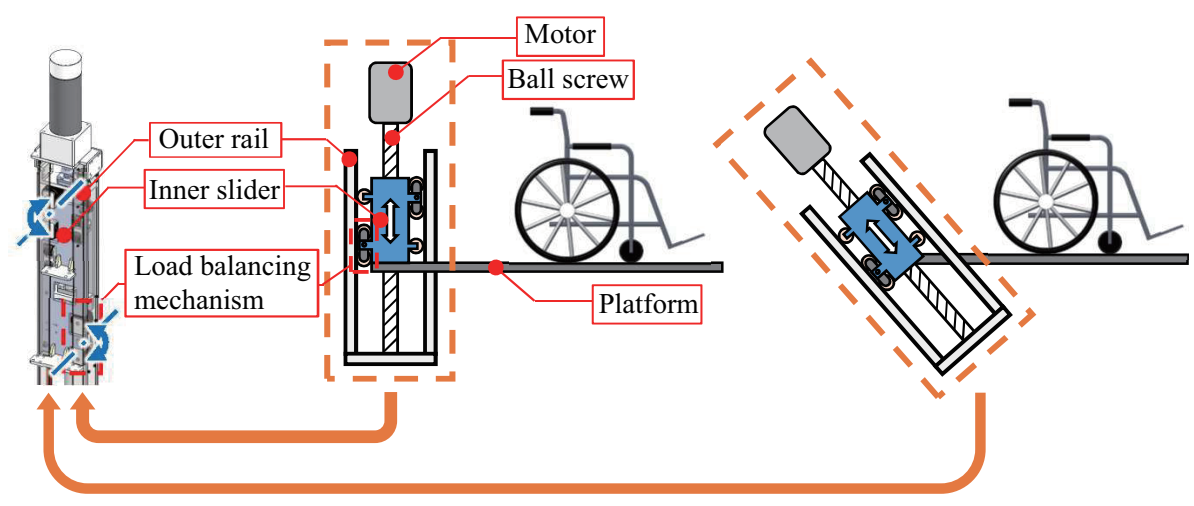

Fig. 2 Lifting slider.

テムには，脱輪防止のために車止めなどが設置してあり，これらは手動または昇降駆動とは別のアクチュエータに よって動かされている．また，前述したように下階側を専有しないようにするためには，プラットフォームの収 納などの機能を増やす必要がある.アクチュエータ数の増加はシステムの規模も増加し, 導入への敷居が高くな るため, 本研究では昇降動作の 1 自由度動作を利用して, プラットフォームの折りたたみや車止めの開閉を行う. 以上の理由から，車いす用昇降支援システムの設計コンセプトは，1）下階側を専有しないシステム，2)段差・階 段共用システム，3) 駆動部分のみにアクチュエータを用いたシステム，の3つとする.

前章で説明した，階段昇降機や段差昇降機は駆動機構が大きく異なることから，システムの共用が難しい課題 が挙げられる．また，福祉車両に用いられているアーム式の昇降リフトは駆動機構を段差と階段で大きく変更しな くても良い反面, 階段や段差が大きい場合, アーム自体がのサイズが大きくなることや, 昇降動作中にシステム へ加えられるモーメントが大きくなる等の課題が挙げられる.そこで, コンセプトに基づき本研究で提案する段 差・階段共用システムの概要図を図 1 に示す. 図のように, 駆動レールに対してプラットフォームを水平になる ように取り付け，昇降駆動を行うシステムとする．本方式は，駆動レールの傾きを段差や階段に対して傾きや長 さを変更するだけで，様々な条件に対応することが可能になると考えられるため, 従来提案されている階段・段 差昇降機に対して同一のシステムで様々な段差や階段の設置条件に対応可能であると考えられる.レールの段差 や階段への取り付けでは, 車いすの負荷による引つ張りおよびモーメントを考慮しつつ, 下階側への張り出しを 少なくするために, 図 1 に示すように段差では上階と下階の 2 か所で強固に固定を行い, 階段では各段に対して レール下部に取り付け部品を用いて下から支える形で強固に固定を行うこととする.

\section{$2 \cdot 2$ 昇降駆動機構}

段差および階段システムの両方で使用する 1 自由度昇降駆動機構について説明する．図 2 に設計した昇降スラ イダの 3DCAD 図を示す．昇降駆動機構は大きく3つの部分（モータ，インナースライダ，アウターレール）に分 かれている，本機構は，防塵性や省スペース性を考慮し，アウターレール内をインナースライダが移動する構造 とした．アウターレールにはリップ溝形状の鋼材を使用し，アウターレール内をインナースライダがスライドす る機構により昇降動作が行われる，昇降の直動運動はボールねじをモータ（本研究では DC モータを使用）で駆 動させることにより行う.モータには電磁ブレーキが取り付けてあり, 電源が遮断された場合にボールねじの回転 


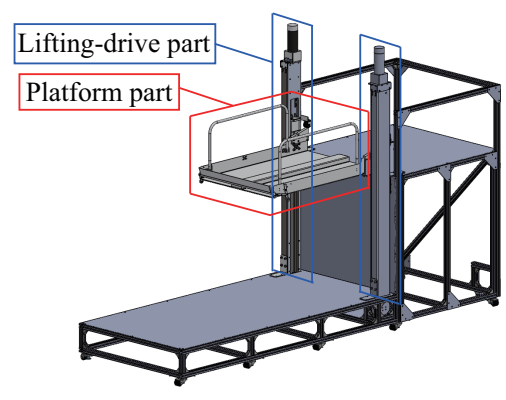

(a) 3D-CAD model.

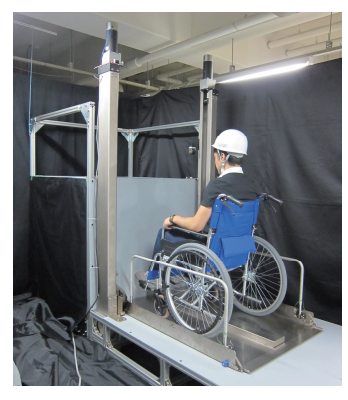

(b) Actual model.

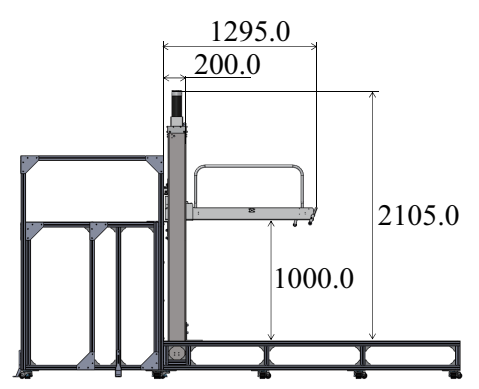

(c) Size.

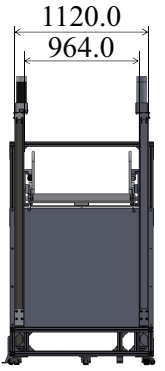

Fig. 3 Steplift.

を保持し，搭乗者が落下しないようになっている.

インナースライダには複数のローラが設置してあり，インナースライダに負荷されるモーメントを支持する役 割とインナースライダがアウターレール内をスライドする際のガイドの役割がある. 一般に荷重を支持するロー ラには，ベアリング等の金属製ローラとキャスターやコンベア等に使用される樹脂製ローラがある．金属製ロー ラは，非常に小型で高強度であることが挙げられるが，磨耗が大きい，一方で，樹脂ローラは磨耗に強いが，金 属製と同等の強度を持たせるためには形状が大きくなってしまう．提案するシステムでは，ローラとアウターレー ル間に非常に大きな荷重が負荷され，磨耗の影響が高くなることを考慮し，樹脂製ローラを採用している．イン ナースライダは, 各方向のモーメントを支持するためのローラ, 直動駆動のためのボールねじナットを備える. こ こで，インナースライダがアウターレール内をスライドする際，ローラがアウターレールに対して常に接触し，各 ローラに加わる荷重が一定になる機構が必要であるために, 荷重分散機構を考案した. 本機構は荷重支持用ロー ラが 2 対構造となっており，中央の軸を中心に回転することが可能である. 前後方向ローラは $\pm 5.5 \mathrm{deg} .$, 左右方 向ローラは $\pm 9.5 \mathrm{deg}$. 回転することができる.この 2 対構造の荷重支持ローラを図 2 のようにインナースライダプ レートに対して対角に配置することで，ローラがレール内を常に接触しながら昇降可能となる．段差昇降および 階段昇降でプラットフォームを水平に保つためにプラットフォームとインナースライダの間の接続方法は変わる が，スライダーの内部構造は同一の機構で構成することができる.

\section{3. 段差昇降システム}

本章では，段差昇降に対応したシステムについて説明する．図 $3 \mathrm{a}$ および図 $3 \mathrm{~b}$ に階段昇降システムの外観およ び実際に製作したシステムの写真を示す. 本システムは昇降駆動部，プラットフォーム部の 2 つ要素によって 構成されている. 昇降駆動部は前章で説明した昇降駆動機構を用いており, 図 4 に示すように, 対角線上に配置 された荷重分散ローラによってプラットフォームに加わる荷重が分散される構造となっている. プラットフォーム 部は車いすが実際に搭乗するステージおよび，未使用時にステージを収納するための折りたたみ機構，そして安 全装置として車いすを停止させる車止機構から構成されている．提案するシステムは一般家庭における玄関先 や車庫・カーポートなどを想定しているため, 本研究では段差の高さを $1000 \mathrm{~mm}$ と想定し, 昇降動作の移動量を $1000 \mathrm{~mm}$ とした．プラットフォームは折りたたみ機構によって上階側で折り畳みを行うことが可能であり，下階 側を大きく専有しないシステム構成となっている.

\section{$3 \cdot 1$ プラットフォーム}

実際に車いすが搭乗する部分である，プラットフォームの拡大図を図 5 に示す。プラットフォームのステージの 形状は，ステージ先端のたわみ量と重量を考慮し，上開口凹形とした。材料の厚みなどの寸法については，人と 電動式車いすが乗ることを想定した強度解析を行い, 設計した. 実際の使用状況を考えた場合, プラットフォー ムと地面との間に人が挟み込まれることが考えられるため，スイッチや近距離センサ等をプラットフォーム下面 に取り付けることで挟み込みを防ぐことが可能であると考えられる. 


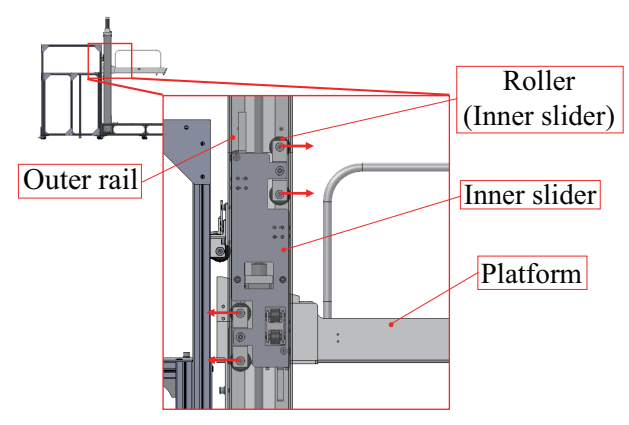

Fig. 4 Connection between the stage of platform and rail.

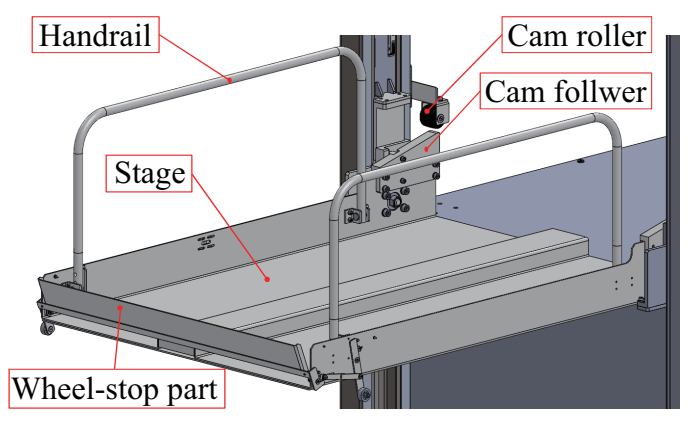

Fig. 5 Platform for the steplift system.

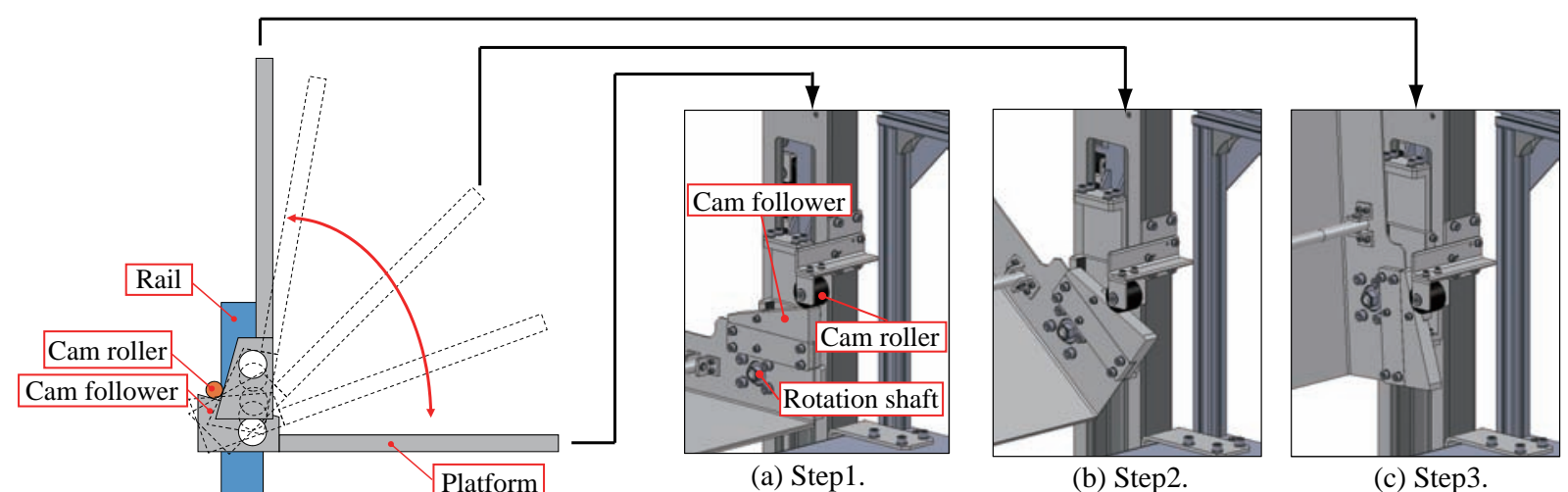

Fig. 6 Folding of the platform.
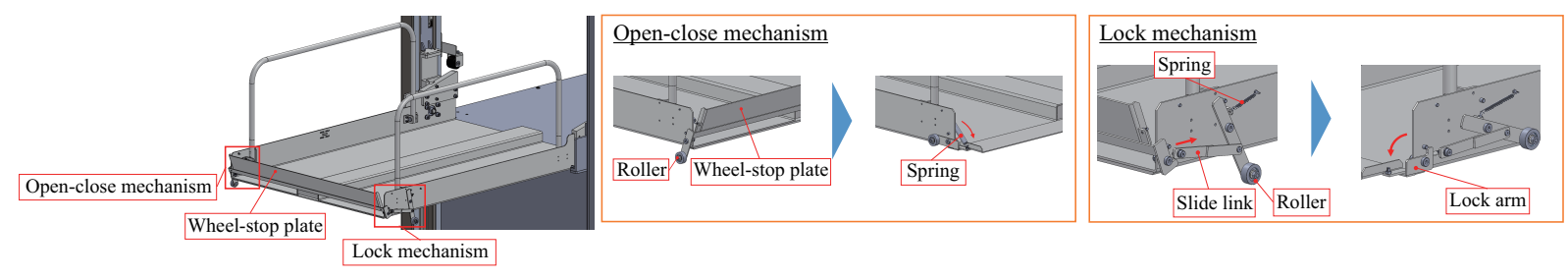

Fig. 7 Wheel-stop mechanism.

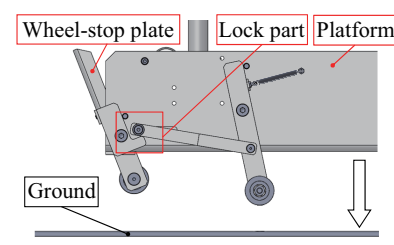

(a) Step1.

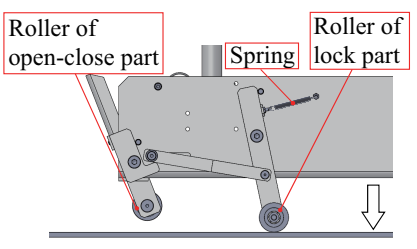

(b) Step2.

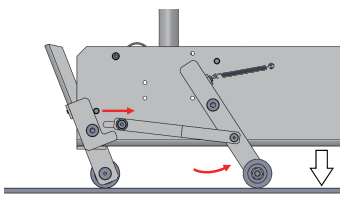

(c) Step3.

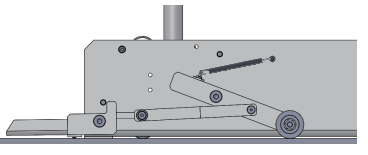

(d) Step4.

Fig. 8 Lock and open-close mechanism procedure.

\section{$3 \cdot 2$ 折り畳み機構}

本節ではプラットフォームの折りたたみ機構について説明する. 本機構はアウターレールに設置されたカムロー ラとプラットフォームに設置されたカムフォロアから構成されている. プラットフォームとインナースライダの 接続部分は, ベアリングとシャフトで軸方向のみ固定されており，プラットフォーム自体はシャフト軸を中心に自 由に回転することができる.ただし, 通常時は水平を保たなければならないため, ストッパによって図 6 中の左 方向の回転を制限している。

折り畳みの手順を図 6 に示す. 図 6 (a) Step1 は上階停止位置からさらにプラットフォームを上昇させ，カムロー ラとカムフォロアが接触した瞬間を表している.この状態でカムローラとカムフォロワの接触点がプラットフォーム の回転軸よりも右側に存在しているため, そのまま上昇を行うと回転軸回りにモーメントが発生し, 図 6 (b) Step2 


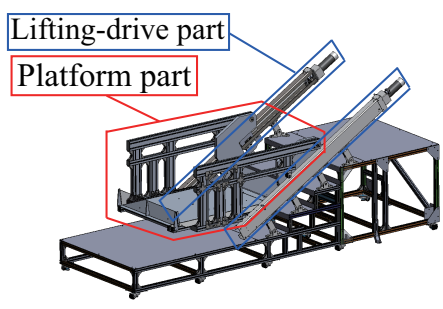

(a) 3D-CAD model.

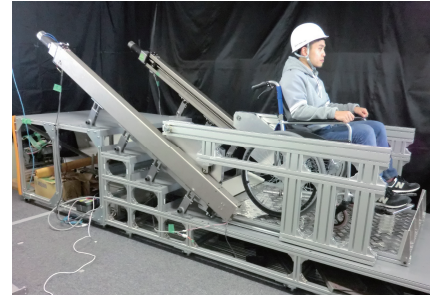

(b) Actual model.

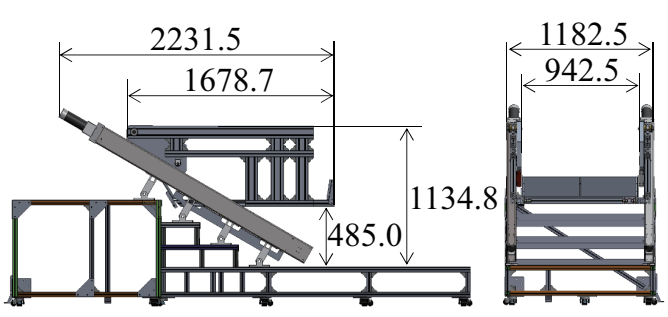

(c) Size.

Fig. 9 Stairlift.

のように回転動作を行う. 最終的に図 6 (c) Step3 の状態まで折り畳みが行われる. 垂直状態では逆向きにプラット フォームが回転する可能性があるため, 折り畳み時の最大傾斜角度は $86 \mathrm{deg}$. としている. 本機構はカムローラと カムフォロアの接触に起因する回転モーメントとプラットフォームの自重による回転モーメントが釣り合うこと で安定を維持している．よって，垂直状態だと釣り合いが発生せず不安定な状態になってしまい，下降時に展開 と逆向きにプラットフォームが回転するなど，目的の動作が実現できない可能性があるため，折り畳み角度の最 大值を $86 \mathrm{deg}$. としている.

\section{$3 \cdot 3$ 車止め機構}

図 7 に示す，アクチュエータを追加せずに車止めの開閉を昇降駆動を利用して行うプラットフォームの車止め機 構について説明する. 本研究で提案する車止め機構は, 開閉機構およびロック機構の 2 つから構成されており, 昇 降駆動によって開閉を行うために，プラットフォームと地面の接触を利用する．従来研究として，小林らが本研究 と同様に昇降機の昇降動作を利用した車止めの開閉およびロック機構を提案している (小林, 2005). 小林らの方法 ではプラットフォームへ車止め開閉のためのカムおよび車止めの開閉を防ぐためのロック機構を設け，地面へカム を回転させるためのローラを取り付けることで, 地面とプラットフォームの接触を利用した車止めの開閉を可能に しているが, 本研究で提案する機構は全てプラットフォーム側へ設け, 地面側には部品を追加しないこととする. 開閉機構は，車止めプレートの片側側面に開閉アームと樹脂ローラ，バネから成り立つ. 展開手順は，はじめに プラットフォームが下降し, 下階地点付近で樹脂ローラが地面と接触することでモーメントが発生し, 展開アー ムが回転することでプレートが展開する，収納手順は，開閉機構内側に設置されたバネによって，ローラが下階 から離れた際に設置したバネの復元力によりプレートが収納できる仕組みとなっている．このようにローラと地 面の接触を利用し，アームが受動的に回転することで, 昇降駆動を利用した開閉が可能になる．しかし，プレー トが収納される力はバネの復元力のみであるため, 仮に昇降動作中にプラットフォーム内部よりプレートに対し てこの復元力以上の力が印加された場合, プレートは容易に展開してしまい, 車止め本来の役割をなさないため, 昇降中は内部からの力でプレートが展開できないようにロック機構を設ける．ロック機構は車止めプレートに対 して開閉機構部の反対側に位置し，スライドリンクとロックアーム，樹脂ローラ，バネから成り立つ.

図 8 にロック機構および開閉機構の動作手順を示す. 図 8a の状態からプラットフォームが下降し，はじめに図 $8 \mathrm{~b}$ のようにロック機構側の樹脂ローラが地面と接触する. すると, 図 8c のようにロックアームが左方向へ回転し, スライドリンクが右ヘスライドすることで, 開閉機構のロックが解除される. その後, 開閉機構側のローラが地 面と接触し, 最終的に図 $8 \mathrm{~d}$ のようにプレートが展開される仕組みとなっている. プレートの収納については，上 記と逆の手順である．スライドリンクの上部には，バネが設置してあるため，その復元力によってアームは回転 し, リンクの先端が左ヘスライドすることでロックが掛かる. 以上の機構により, プラットフォームが下階地点付 近に位置するときのみ車止めのロックが解除され，車止めが開閉することができる.

\section{4. 階段昇降システム}

本章では，階段昇降に対応したシステムについて説明する．図 9a に階段昇降システムの外観を，図 $9 \mathrm{~b}$ に実際 に製作したシステムを示す. 本システムは段差対応システムと同様に昇降駆動部，プラットフォーム部の $2 つ の$ 要素によって構成されている．昇降駆動部は第 2 章で説明した昇降駆動機構を用いている. 

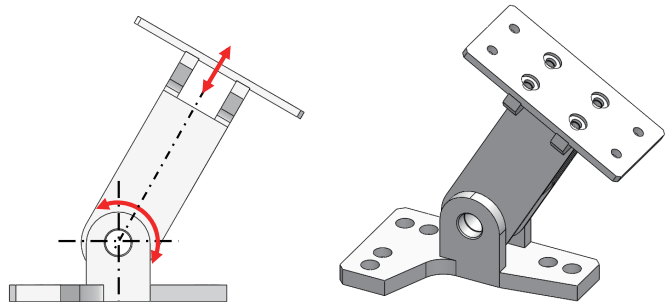

Fig. 10 Fixture for stairlift.

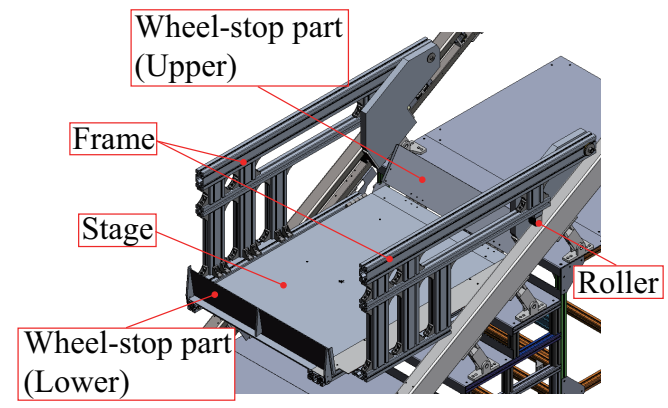

Fig. 12 Platform for the stairlift system.

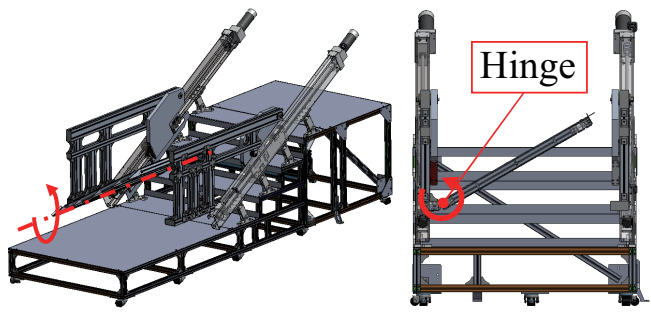

Fig. 11 Folding of the platform.

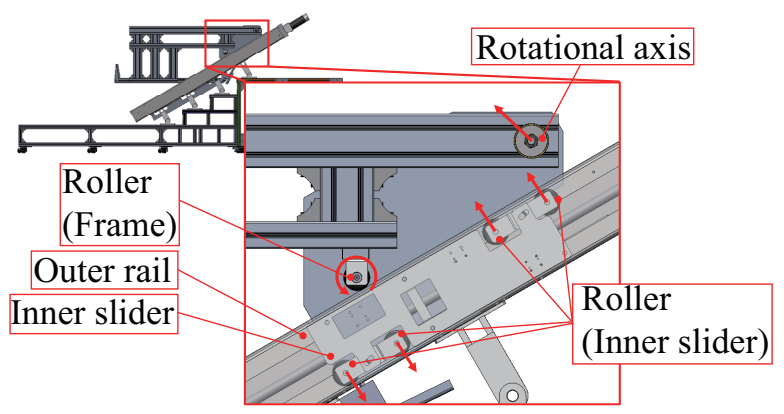

Fig. 13 Connection between the platform and rail.

階段昇降システムが段差昇降システムと異なる点として, レールの固定方法およびプラットホームの機構が挙 げられる. 昇降駆動部は様々な階段に対応して設置を行うため, レール固定部品を用いて階段と固定を行う. そ こで，様々な傾斜の階段に対応するために，図 10 のようにレール固定部は回転と並進が可能なように 2 自由度を 持たせる.レール固定部品は, 段差昇降システムと同様に最大荷重 $250 \mathrm{kgf}$ で耐えられるように設計した. プラッ トフォーム部は車いすが実際に搭乗するステージおよび，未使用時にステージを収納するための折りたたみ機構， そして安全装置として車いすを停止させる車止機構から構成されている．段差対応システムでは，ステージの 片端が段差の面であったため，片端のみ車止め機構を用いていたが，階段対応システムでは階段の上階側および 下階側の両方に車止機構が必要となる. プラットフォームは段差昇降システムと異なり, 図 11 に示すように, 片開き構造とし横へ折り畳めるように設計した．プラットフォームが上階に到達しているときに折り畳むことで, 未使用時には階段のまま使用することができ，なおかつ下階側のスペースを専有しない．

$4 \cdot 1$ プラットフォーム

階段昇降システムのプラットフォームの拡大図を図 12 に示す. 階段昇降システムのプラットフォームは, 段差 昇降システムのプラットフォームと収納方法や昇降駆動レールとの連結方法が異なるため, 本研究では段差昇降シ ステムのプラットフォームと同様の耐荷重（250 kgf）で耐えられるようにアルミフレームを用いて設計した．プ ラットフォームは車いすが搭乗するためのステージ，ステージと昇降駆動レールを連結するフレーム，上階側と 下階側の車止機構から成り立っている．階段昇降システムでは，図 13 に示すように，フレームと昇降駆動レー ルの間の結合を回転軸にすることで，フレームに取り付けたローラが常にアウターレールの上面に接触すること ができる．フレーム側のローラをインナースライダの上下のローラの間に配置し，回転軸をインナースライダの 上側のローラよりも上側へ配置することにより，フレーム側のローラ周りにトルクを発生させることができ，全 てのローラに荷重を分散させることができる.

\section{$4 \cdot 2$ 車止め機構}

次に，車止め機構について説明する．階段昇降システムでは下階側と上階側の 2 方向に対して車止め機構を取り 付けなければならない，下階側の車止め機構に関しては，段差昇降システムでの機構を応用可能であるため，本節 では上階側の車止め機構について説明する. 車止め機構は開閉プレート側にカムフォロアを設置し, 昇降レール の下部にカムレールを設置している．図 14 に昇降動作に合わせて車止め機構が開閉する様子を示す．車止め機構 


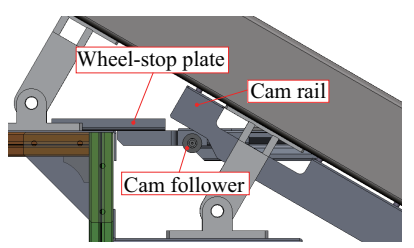

(a) Step1.

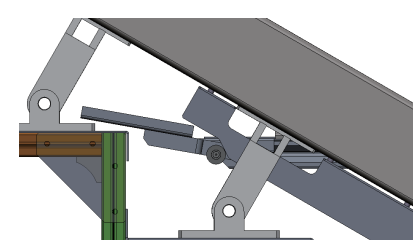

(b) Step2.

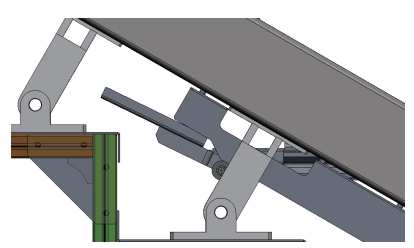

(c) Step3.

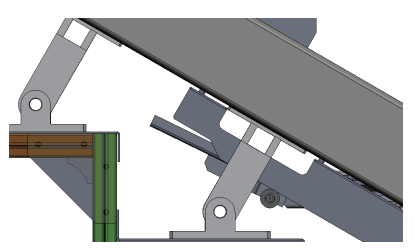

(d) Step4.

Fig. 14 Open-close mechanism procedure for the upper wheel-stop mechanism.

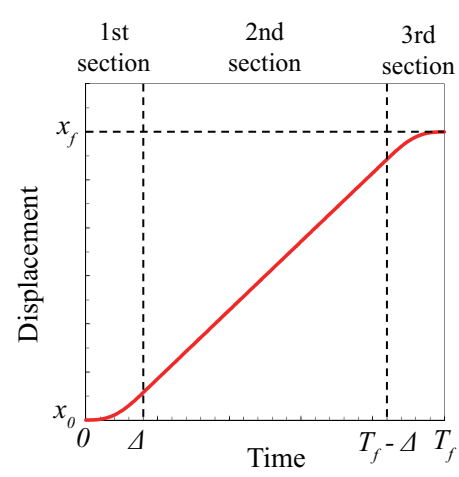

Fig. 15 The section of 4-1-4th order polynomial interpolation.

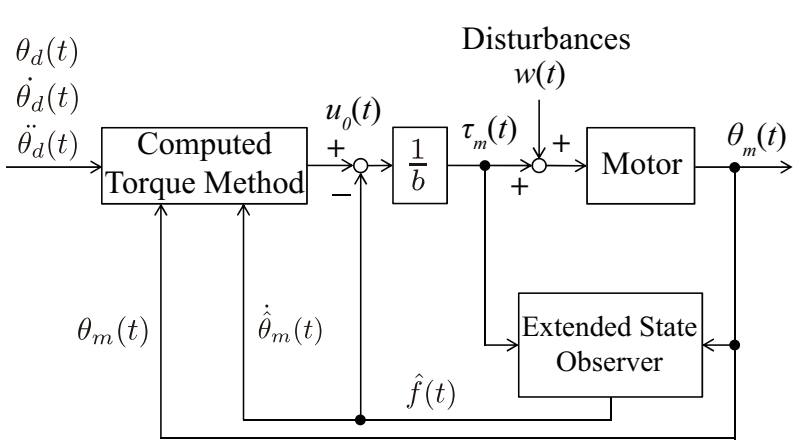

Fig. 16 Block diagram of the control system with ESO.

は，開閉プレート側に重心を設定しているため，自重でカムフォロアはレールに押し付けられた状態となり，カム フォロアはプラットフォームの昇降動作に合わせてレールの上を転がりながら移動する．カムレールは上階側に 到達すると, レールの幅が狭くなっているため, 昇降動作に合わせて自動的に開閉プレートが開くことができる. 以上の機構から，アクチュエータを増やさずに昇降動作を利用して車止め機構の開閉を実現することができる.

\section{5. 制 御システム}

\section{$5 \cdot 1$ 軌道生成}

本システムは，始点と終点の座標および目標時間から軌道を生成する PTP(point to point) 制御を使用する. 代表 的な PTP 軌道生成法として 5 次多項式補間軌道が挙げられるが，通過点のある場合に通過時刻を適切に選ばないと 振動が生じる. 本研究では始点から終点座標までを複数の区間に分け，4 次多項式と 1 次多項式を併用した 4-1-4 次 多項式補間軌道を用いる。 4-1-4 次多項式補間では, 最終目標時間 $T_{f}$, 立ち上がり（立ち下がり）時間 $\Delta\left(<T_{f} / 2\right)$, 始点の座標 $x_{0}$, および終点の座標 $x_{f}$ によって軌道を決定することができる.

\section{$5 \cdot 2$ 外乱補償制御を用いたモー夕制御方法}

モータの制御には計算トルク法を用いる。モータの目標角度, 目標速度, 目標角速度をそれぞれ $\theta_{d}, \dot{\theta}_{d}, \ddot{\theta}_{d}$ とお き，モータの角度を $\theta_{m}$ とおくと，その制御則は

$$
\tau_{m}=J\left[\ddot{\theta}_{d}-K_{P}\left(\theta_{d}-\theta_{m}\right)-K_{D}\left(\dot{\theta}_{d}-\dot{\theta}_{m}\right)\right]+D \dot{\theta}_{m}
$$

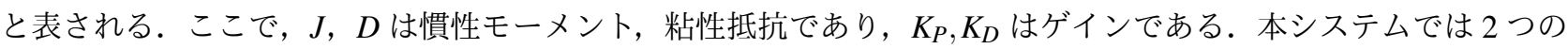
アクチュエータを使用しているが，それぞれのアクチュータの間で同期は取らずに，個別で制御ループを構築し ている.

計算トルク法では外乱のない理想的なシステムを考えているが，実際には摩擦や重力等の影響により外乱が生 じるため, 応答およびロバスト性の向上を図るために制御系へ外乱補償器を導入する. 本研究では, 外乱補償器 として拡張状態オブザーバ (Extended State Observer:以下 ESO) を用いる (Zheng et. al., 2012)(近藤他, 2015). ESO 
は未知の外乱や誤差を含むシステムに対する制御手法として有用であることが知られており，モデル同定が不要 なため，オブザーバの設計のみで外乱推定が可能な利点がある.

本システムは, 入力が各モータへ加えるトルク $\tau_{m}=\left[\tau_{m 1}, \tau_{m 2}\right]^{T}$, 出力がエンコーダにより計測される各モータ の回転角度 $\boldsymbol{\theta}_{\boldsymbol{m}}=\left[\theta_{m 1}, \theta_{m 2}\right]^{T}$ となるので, システムのダイナミクスは,

$$
\left[\begin{array}{l}
\ddot{\theta}_{m 1} \\
\ddot{\theta}_{m 2}
\end{array}\right]=\left[\begin{array}{l}
f_{1}\left(\dot{\theta}_{m 1}, \theta_{m 1}, w_{1}(t)\right) \\
f_{2}\left(\dot{\theta}_{m 2}, \theta_{m 1}, w_{2}(t)\right)
\end{array}\right]+\left[\begin{array}{l}
b_{1} \tau_{m 1} \\
b_{2} \tau_{m 2}
\end{array}\right]
$$

と表される。ここで，計算トルク法 (式(1))を適用すると各モータの制御則は,

$$
\left[\begin{array}{c}
\tau_{m 1} \\
\tau_{m 2}
\end{array}\right]=\left[\begin{array}{l}
\left(\ddot{\theta}_{d 1}+K_{p 1}\left(\theta_{d 1}-\theta_{m 1}\right)+K_{d 1}\left(\dot{\theta}_{d 1}-\dot{\hat{\theta}}_{m 1}\right)-\hat{f}_{1}\right) / b_{1} \\
\left(\ddot{\theta}_{d 2}+K_{p 2}\left(\theta_{d 2}-\theta_{m 2}\right)+K_{d 2}\left(\dot{\theta}_{d 2}-\dot{\hat{\theta}}_{m 2}\right)-\hat{f}_{2}\right) / b_{2}
\end{array}\right]
$$

で求められる.ここで, $\hat{f}_{1}, \hat{f}_{2}$ が ESOによって推定された外乱を表す. 図 16 に ESO による外乱補償を加えたシス テム全体のブロック線図を示す.

\section{6. 昇 降駆動 実 験}

実際に製作した段差および階段昇降システムについて実験から昇降駆動の確認を行う.

\section{1 段差昇降システムによる実験}

\subsection{1無負荷および左右均等に荷重を加えた場合}

負荷荷重による定常偏差の変化を確認するために，プラットフォームに荷重を負荷しない状態および左右均等 に荷重を負荷した状態で実験を行う。プラットフォームに 0-200 kgf の荷重を $40 \mathrm{kgf}$ 間隔で負荷させ. 昇降駆動を 行う. 実験の様子を図 $17 \mathrm{a}$ に示す．負荷荷重位置は車椅子の後輪位置付近である，プラットフォーム根元から 900 $\mathrm{mm}$ 地点とした.

4-1-4 次多項式補間において, 加速および減速時間 $\Delta=3.5[\mathrm{~s}]$, 目標時間 $T_{f}=40.0[\mathrm{~s}]$ および目標移動距離 $x_{f}=990[\mathrm{~mm}]$ として上昇および下降動作を行った。昇降駆動については, 計算トルク法のみを用いた場合と計算 トルク法に外乱補償器を加えた場合の両方で実験を行う.

各負荷荷重に対する最大偏差の結果を表 1 に示す。一例として, 負荷荷重が $200 \mathrm{kgf}$ の場合の上昇時のグラフを 図 18a に示す. 図 18bに $38.0 \mathrm{~s}-41.0 \mathrm{~s}$ の実験結果の拡大図を示す. 実験結果より, システムが正常に昇降駆動し ており, 始点と終点付近で適切に加減速を行っていることが確認できる. 図中の破線が ESO を適用していない場 合における実際の軌道を表しており，実線が ESO を適用した場合における実際の軌道を表している．ESO を適用 していない場合，摩擦や負荷荷重の影響で定常偏差が残っているが，ESO の適用で定常偏差の大きさを大きく低 減されている. 実験結果から, 外乱補償器によって定常偏差が全体的に大幅に減少しており, 負荷荷重の増加によ る偏差の変化も小さいことが確認された.

図 $18 \mathrm{~b}$ において，減速時に位置の軌道に摇れが発生しているが，これは一定速度から減速を行うことでプラッ トフォームと錘の慣性によって発生したと考えられる. しかし，摇れの大きさが $1 \mathrm{~mm}$ 以下と非常に小さいため, システムは十分滑らかに動作しており，実用上問題ないと考えられる.

\subsection{2 偏荷重の場合}

次に，プラットフォーム左右に偏荷重を負荷した昇降駆動実験を行う. 図 $17 \mathrm{~b}$ に示すようにプラットフォーム の左側に $120 \mathrm{kgf}$, 右側に $80 \mathrm{kgf}$ の偏荷重を負荷させる. 負荷荷重位置はプラットフォーム根元から $900 \mathrm{~mm}$ 地点 とした。その他の実験条件および，目標軌道は等分荷重の実験と同様の条件であり，昇降駆動はESO を適用させ た状態で行った.

図 19a に偏荷重をかけた状態での上昇動作の結果を示す．また，図 $19 \mathrm{~b} に 38.0 \mathrm{~s}-41.0 \mathrm{~s}$ の実験結果の拡大図を 示す. 実験結果から, ESO を加えることで, 偏荷重が負荷されても, 左右モータの偏差はほとんど見られないこと がわかる. 以上から, 左右に異なる外乱を加えた状態でもプラットフォームをほぼ平行に保ちつつ (左右偏差 0.05 $\mathrm{mm})$ 昇降動作が可能である. 


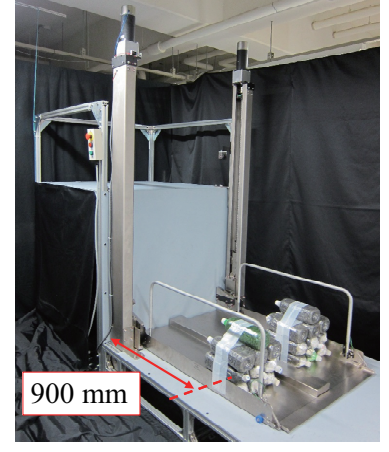

(a) Case: equally divided load.

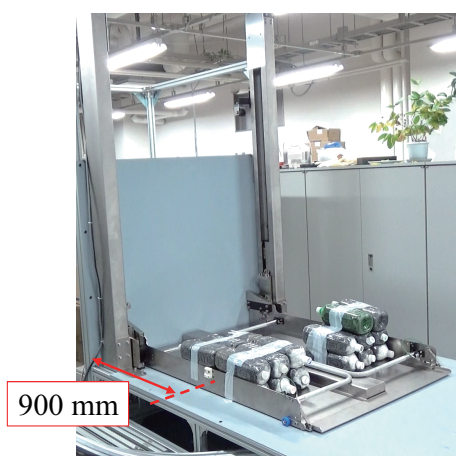

(b) Case: unbalanced load.
Table 1 Stationary error

\begin{tabular}{|c|c|c|}
\hline Load [kgf] & CT [mm] & ESO [mm] \\
\hline \hline 0 & 0.44 & 0.11 \\
\hline 40 & 0.54 & 0.12 \\
\hline 80 & 0.64 & 0.11 \\
\hline 120 & 0.71 & 0.13 \\
\hline 160 & 0.86 & 0.19 \\
\hline 200 & 0.91 & 0.17 \\
\hline
\end{tabular}

Fig. 17 Experimental setup.

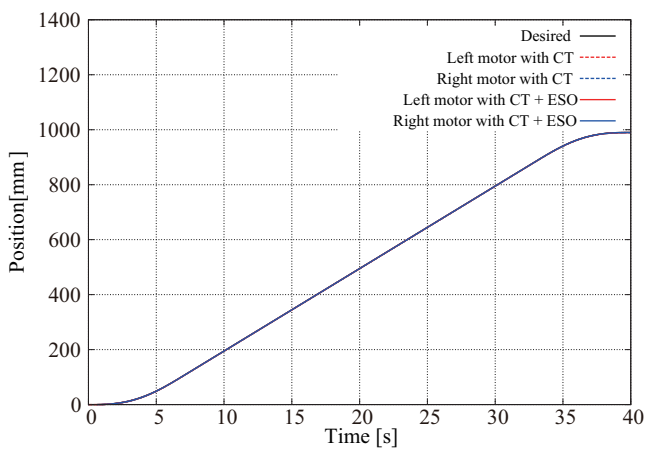

(a) All.

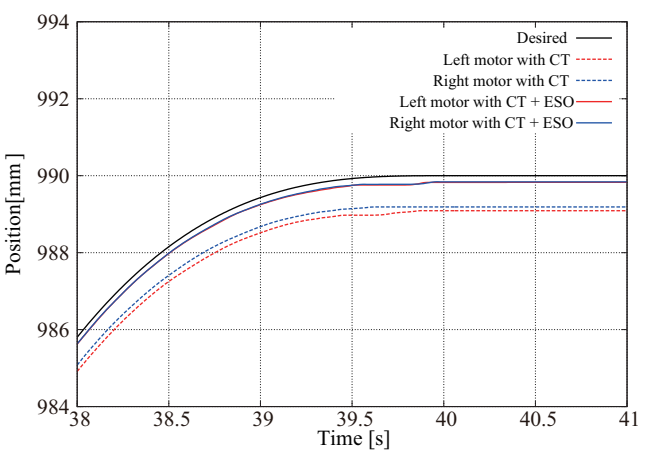

(b) Enlarged.

Fig. 18 The result of $200 \mathrm{kgf}$ lifting experiment.

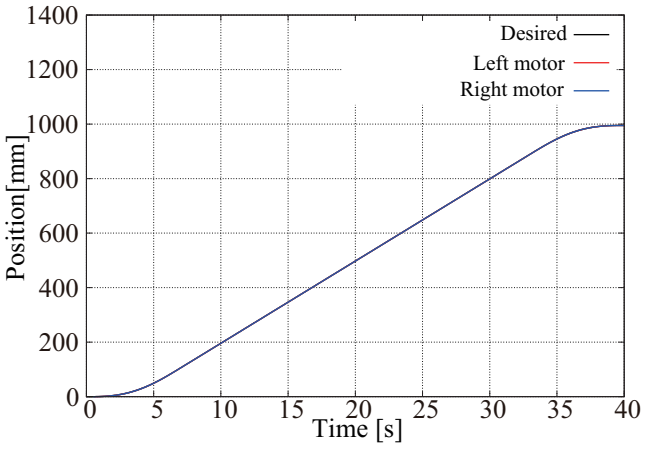

(a) All.

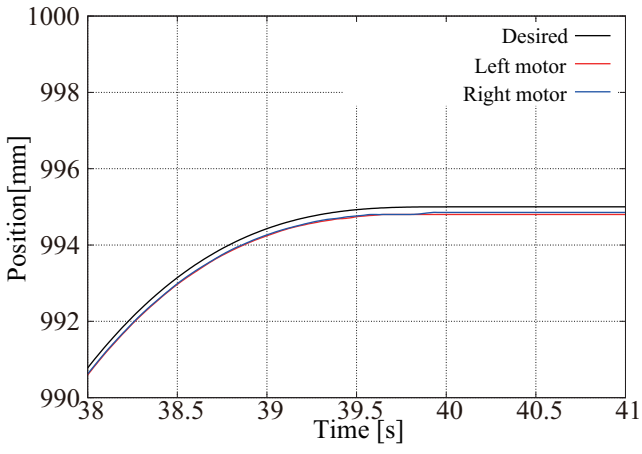

(b) Enlarged.

Fig. 19 The result of unbalanced load experiment.

\section{$6 \cdot 2$ 階段昇降システムの昇降駆動実験}

\section{6·2・1 無負荷および左右均等に荷重を加えた場合}

階段昇降システムでも段差昇降システムと同様，負荷荷重による定常偏差の変化を確認するために，プラット フォームに荷重を負荷しない状態および左右均等に荷重を負荷した状態で実験を行う。プラットフォームに0-200 $\mathrm{kgf}$ の荷重を $40 \mathrm{kgf}$ 間隔で負荷させた。実験の様子を図 $20 \mathrm{a}$ に示す．負荷荷重位置は車椅子の後輪位置付近であ る，プラットフォーム根元から $800 \mathrm{~mm}$ 地点とした.

4-1-4 次多項式補間において, 加速および減速時間 $\Delta=3.5[\mathrm{~s}]$, 目標時間 $T_{f}=40.0[\mathrm{~s}]$ および目標移動距離 $x_{f}=972[\mathrm{~mm}]$ として上昇および下降動作を行った。実験は全て計算トルク法および外乱補償器を用いた状態で実 験を行った.

各負荷荷重に対する最大偏差の結果を表 2 に示す。一例として，負荷荷重が $200 \mathrm{kgf}$ の場合の実験結果を図 $21 \mathrm{a}$ に示し，38.0 s - 41.0 s の拡大を図 $21 \mathrm{~b}$ に示す。図中の破線が ESO 適用していない場合における実際の軌道を表 
Seino, Kinugawa, Wakabayashi, Itami, Buranaamon and Kosuge,

Transactions of the JSME (in Japanese), Vol.85, No.874 (2019)

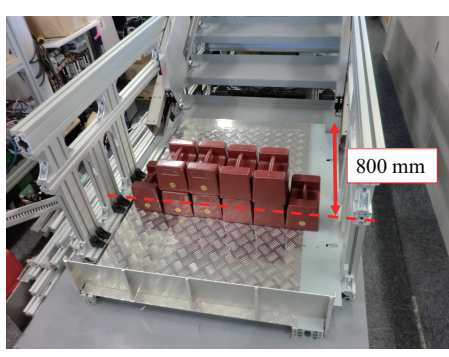

(a) Case: equally divided load.

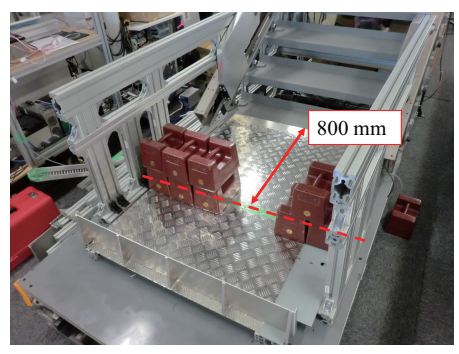

(b) Case: unbalanced load.

Table 2 Stationary error.

\begin{tabular}{|c|c|c|}
\hline Load [kgf] & CT [mm] & ESO [mm] \\
\hline \hline 0 & 0.35 & 0.06 \\
\hline 40 & 0.40 & 0.06 \\
\hline 80 & 0.50 & 0.08 \\
\hline 120 & 0.50 & 0.09 \\
\hline 160 & 0.56 & 0.09 \\
\hline 200 & 0.65 & 0.12 \\
\hline
\end{tabular}

Fig. 20 Experimental setup.

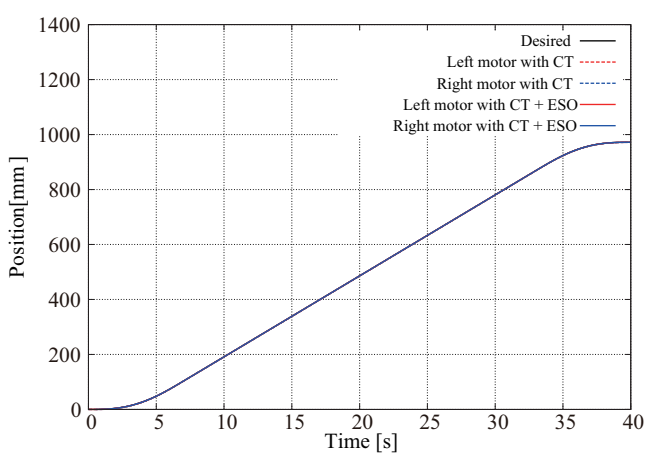

(a) All.

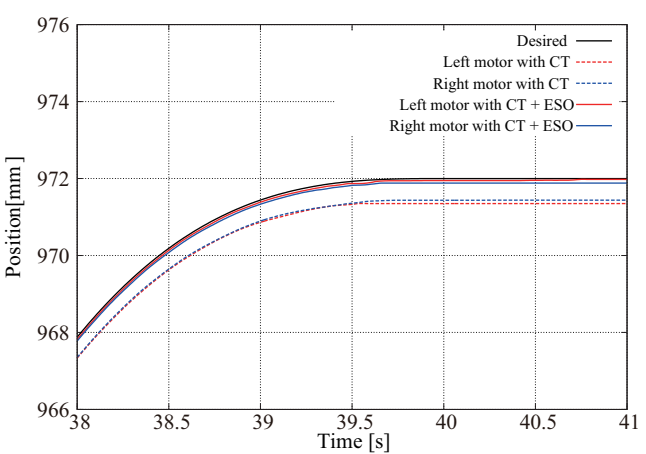

(b) Enlarged.

Fig. 21 The result of $200 \mathrm{kgf}$ lifting experiment.

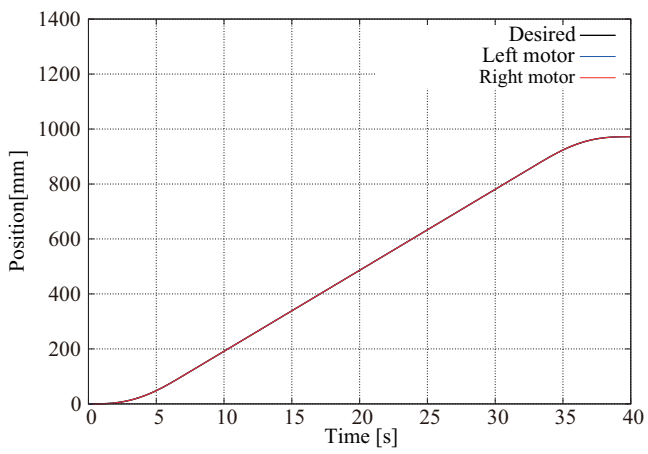

(a) All.

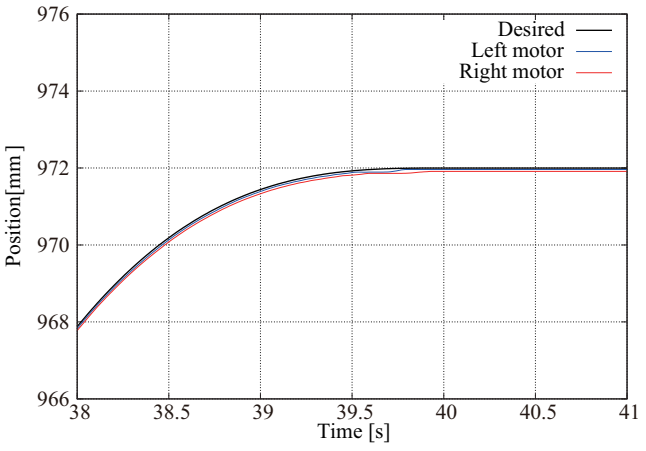

(b) Enlarged.

Fig. 22 The result of unbalanced load experiment.

しており，実線がESO を適用した場合における実際の軌道を表している．階段昇降システムではプラットフォー ム片開き構造になっているため，プラットフォームが連結されている左側のレールの偏差が大きくなっているが， 最大荷重でも偏差が非常に小さいことが確認できた。実験から, 階段昇降システムにおいても段差昇降システム と同様の昇降動作を行ことができることを検証した。

段差昇降システム同様，図 21aにおいて減速時に軌道に摇れが発生しているが，これも同様に一定速度から減 速を行うことでプラットフォームと錘の慣性によって発生したと考えられる．本実験でも摇れの大きさが $1 \mathrm{~mm}$ 以 下と非常に小さいため，システムは十分滑らかに動作しており，実用上問題ないと考えられる.

\subsection{2 偏荷重の場合}

次に，プラットフォーム左右に偏荷重を負荷した昇降駆動実験を行う．図 $20 \mathrm{~b}$ に示すようにプラットフォーム の左側に $120 \mathrm{kgf}$ ，右側に $80 \mathrm{kgf}$ の偏荷重を負荷させる．負荷荷重位置はプラットフォーム根元から $800 \mathrm{~mm}$ 地点 としたそその他の実験条件および，目標軌道は等分荷重の実験と同様の条件であり，昇降駆動は ESO を適用させ た状態で行った。

図 22a に階段昇降システムに偏荷重を加えた状態での上昇動作の結果を示す。また，図 $22 \mathrm{~b} に 38.0 \mathrm{~s}-41.0 \mathrm{~s}$ の 
実験結果の拡大図を示す。実験結果から，階段昇降システムも段差昇降システム同様に，偏荷重が加えられた状 態でもプラットフォームをほぼ平行に保ちつつ（左右位置偏差 $0.05 \mathrm{~mm}$ ）昇降駆動可能である. 以上の結果から, 階段昇降システムの場合でも, 段差昇降システムと同様に等分荷重や偏荷重を加えた状態で昇降動作が可能であ ることが示された。

\section{7. 結言}

本稿では，一般家庭での使用を想定した新しい車いす用昇降システムについて提案し，その設計および制御方 法について実験を通して有効性を示した。一般家庭における設置スペースや設置条件の問題を抽出し，それらの問 題を解決するための設計コンセプトを示し，その設計コンセプトに基づいて，駆動レールを用いて様々な段差や 階段に対応できるシステムを提案した。提案するシステムでは，昇降駆動を利用しプラットフォームを折り畳み， 車止め機構を動作させる機構を考案した。また，制御系に関して，モータの制御に応答性およびロバス卜性の向 上を図るために外乱補償器である ESO を導入し，実験から様々な荷重に対する制御の有効性を確認し，階段・段 差昇降システムが目的とする動作を実現できることを示した。

\section{文献}

内閣府, 平成 30 年版高齢社会白書 (全体版) (online), available from 〈 http://www8.cao.go.jp/kourei/whitepaper/w2018/zenbun/pdf/1s1s_01.pdf）（参照日 2018 年 6 月 30 日）。

中央エレベータ工業株式会社, 車椅子式階段昇降機 H350Z (online), available from 〈https://www.steplift.jp/wheelchair/ （参照日 2019 年 1 月 9 日）。

中央エレベータ工業株式会社，車椅子式階段昇降機低揚程タイプ（online)，ａvailableｆrom https://www.steplift.jp/wheelchair/product/mochiage.html〉（参照日 2019 年 1 月 9 日）.

小林裕介, 関啓明, 神谷好承, 正津正利, 前川満良, 車いすの動力を利用した段差解消機の開発, 日本機械学会論文集 C 編, Vol. 71, No. 711 (2005), pp. 3216 - 3222.

近藤修平, Luis CANETE, 高橋隆行, マニピュレータを搭載した車両型倒立振子ロボットの制御 - 拡張状態オブザーバ を用いたマニピユレータによる物体受け渡し制御 -, ロボティクス・メカトロニクス講演会 2015 (2015), 1P2-G03. 株式会社マイクロエレベーター，車いす用階段昇降機 (online), available from 〈 http://www.microev.jp/product/kurumaisu/〉（参照日 2019 年 1 月 9 日）。

三菱日立ホームエレベーター株式会社 (online), available from〈http://www.mh-he.co.jp/ 〉 (参照日 2017 年 1 月 5 日). 国民生活センター，医療機関ネットワーク事業からみた家庭内事故-高齢者編-（online)，available from http://www.kokusen.go.jp/news/data/n-20130328_3.html）（参照日2018 年 8 月 31 日）.

国土交通省住宅局住環境整備室，高齢者住宅施策の現状と動向（online）， available from http://www.mlit.go.jp/common/000027570.pdf ）（参照日 2018 年 8 月 31 日）.

佐々木海, 鈴木健嗣, 受動的な制御により段差踏破する車椅子型移動機器, ロボティクス・メカトロニクス講演会 2015 (2015), 2P1-H03.

SD エレメイク株式会社, 車いす用 段差解消機 (online), available from 〈http://www.elemake.com/wheelchair1.html〉 （参照日 2019 年 1 月 9 日）。

総務省, 日本の住宅・土地 -平成 25 年住宅・土地統計調查の解説- 結果の解説 (online), available from http://www.stat.go.jp/data/jyutaku/2013/nihon.htm〉（参照日 2018 年 7 月 9 日）.

菅原雄介, 米澤直晃, 小菅一弘, 車輪付形状可変型 4 節リンク機構を用いた階段昇降機構, 日本ロボット学会誌, Vol. 29, No. 7 (2011), pp. $599-608$.

柳原直人, 菅沢深, 鈴木夏夫, 金海吉秀, 金丸豊文, 石井崇, 階段昇降可能な電動車いす「QUATTRO-I」の開発, 第 18 回日本ロボット学会学術講演会 (2000), pp. $551-552$.

和光工業株式会社, 介助・介護用リフト (online), available from 〈http://www.wakoindustry.co.jp/hp_dt095/p_info/sl/index.html 〉（参照日 2019 年 1 月 17 日）.

Zheng, Q., Gao, L. Q. and Gao, Z., On validation of extended state observer through analysis and experimentation, Journal of Dynamic Systems Measurement and Control, Vol. 134, Issue 2 (2012), pp. 024505-1 - 024505-5. 


\section{References}

Cabinet Office, Government of Japan, Heisei 30 senior society white paper (whole version) (online), available from $<$ http://www8.cao.go.jp/kourei/whitepaper/w-2018/zenbun/pdf/1s1s_01.pdf > (accessed on 30 June, 2018).

CHUO ELEVATOR INDUSTRY Co. Ltd., Wheelchair type stair lift (H350Z) (online), available from https://www.steplift.jp/wheelchair/ > (accessed on 9 January, 2019).

CHUO ELEVATOR INDUSTRY Co. Ltd., Wheelchair type stair lift (low lifting type) (online), available from https://www.steplift.jp/wheelchair/product/mochiage.html $\rangle$ (accessed on 9 January, 2019).

Kobayashi, Y., Seki, H., Kamiya, Y., Hikizu, M. and Maekawa, M., Development of a non-powered lift for wheelchair users, Transactions of the Japan Society of Mechanical Engineers Series C, Vol. 71, Issue 711 (2005), pp. 3216 3222 (in Japanese).

Kondo, S., Canete, L. and Takahashi, T., Control of wheeled inverted pendulum type assistant robot equipped with a dual manipulator -object hand over control using the extended state observer-, Proceedings of the 2015 JSME Conference on Robotics and Mechatronics (2015), 1P2-G03 (in Japanese).

Micro Elevator Co., Ltd., Stair lift for wheelchair (online), available from $\langle$ http://www.micro-ev.jp/product/kurumaisu/ $\rangle$ (accessed on 9 January, 2019).

MITSHBISHI HITACHI HOME ELEVATOR Corp. (online), available from $\langle$ http://www.mh-he.co.jp/ $\rangle$ (accessed 5 January, 2017).

National consumer affairs center of Japan, Domestic accident seen from medical institution network business - Elderly person edition - (online), available from 〈 http://www.kokusen.go.jp/news/data/n-20130328_3.html $\rangle$ (accessed on 31 August, 2018).

Residential Environment Office, Housing Bureau, Ministry of Land, Infrastructure, Transport and Tourism, Current situation and trend of elderly housing policy (online), available from $\langle$ http://www.mlit.go.jp/common/000027570.pdf $>$ (accessed on 31 August, 2018).

Sasaki, K. and Suzuki, K., A wheelchair device with lever-propulsion step-climbing mechanism, Proceedings of the 2015 JSME Conference on Robotics and Mechatronics (2015), 2P1-H03 (in Japanese).

SD Elemake Co. Ltd., Step lift for wheelchair (online), available from 〈http://www.elemake.com/wheelchair1.html $\rangle$ (accessed on 9 January, 2019).

Statistics Bureau, Ministry of Internal Affairs and Communications, Housing and Land in Japan - Commentary on Heisei 25 housing and land statistics survey - explanation of results (online), available from < http://www.stat.go.jp/data/jyutaku/2013/nihon.htm 〉 (accessed on 9 July, 2018).

Sugahara, Y., Yonezawa, N. and Kosuge, K., A stair-climbing wheelchair with wheeled transformable four-Bar linkage, Journal of Robotics Society Japan, Vol. 29, No. 7 (2011), pp. 599 - 608 (in Japanese).

Yanagihara, N., Sugasawa, F., Suzuki, N., Kanaumi, Y., Kanamaru, T. and Ishii, T., Development of a stair-climbing wheel chair “QUATTRO-I”, Proceedings of the 18th Annual Conference of the RSJ (1999), pp. 551 - 552 (in Japanese).

Wako Industry Co. Ltd., Wako super lift (online), available from < http://www.wakoindustry.co.jp/hp_dt095/p_info/sl/index.html $\rangle$ (accessed on 17 January, 2019).

Zheng, Q., Gao, L. Q. and Gao, Z., On validation of extended state observer through analysis and experimentation, Journal of Dynamic Systems Measurement and Control, Vol. 134, Issue 2 (2012), pp. 024505-1 - 024505-5. 